\title{
The Role of Financial and Monetary Policy in the Economic Activity in Jordan During the Period (2000-2016)
}

\author{
Talal Bataineh ${ }^{1}$ \\ ${ }^{1}$ Faculty of Business, Tafila Technical University, At-Tafila, Jordan \\ Correspondence: Talal Bataineh, Faculty of Business, Tafila Technical University, At-Tafila, Jordan. AT-Tafila, \\ P.O.Box179, Tafila, 66110, Jordan.
}

Received: March 19, 2018

Accepted: April 16, $2018 \quad$ Online Published: April 23, 2018

doi:10.5539/ibr.v11n5p167

URL: https://doi.org/10.5539/ibr.v11n5p167

\begin{abstract}
This study investigated the impact of each of the financial policy and monetary policy on the economic activity on Jordan during the period (2000-2016). The researcher conducted the appropriate statistical analysis (step wise) with the aim of excluding the self- correlation between variables. It was revealed through the analysis that the financial policy in Jordan was more effective, in the influence on economic activity, than the monetary policy. The study concluded a group of results and recommendation, the most important of which was the necessity for, special concern about monetary policy to perform its role together with financial policy in order to raise Jordanian economy toward the best through the increase in co-ordination between both policies.
\end{abstract}

Keywords: financial policy, monetary policy, economic activity, Jordan

\section{Introduction}

\subsection{Introduce the Problem}

The financial and monetary policies are important instruments owned the state for managing economy and which take care of the financial efforts relating to the expenditure and revenue activity of the government. These policies aim at the increase of the growth rate of gross domestic product and limitation of economic fluctuations represented in inflation, unemployment and the achievement of economic equilibrium. The problem of the study lies in the efficiency extent of financial and monetary policies in the achievement of economic equilibrium and limitation of the difficulties which the Jordanian economy suffers from and the achievement of a sufficient level in regard to the allocation of resources between consumption and capital accumulation.

\subsection{Study Questions}

1) Does the financial policy, followed in Jordan through its different instruments, contribute to the treatment of the economic problems which face the Jordanian economy?

2) Does the monetary policy, followed in Jordan through its instruments, contribute to the treatment of the economic problems which face the Jordanian economy?

\subsection{Objectives of the Study}

This study aimed at achieving the various aims sought by each one of the tow policies( financial and monetary ) in the national economy, relying, for that, on the instruments which affect all economic and social aspects of society such as economic growth, stability, employment and the increase in the development rates of gross domestic product.

\subsection{Importance of the Problem}

The importance of the study lies in the importance of the role played by the tow policies, the financial and the monetary, in the economic activity which attracted the interest of a big group of economists as they have their impact on the economic conditions of the financial and the monetary, in the economic activity which attracted the interest of a big group of economists as they have their impact on the economic conditions of the state, as well as being guide the track of economic entity in order to achieve the aims sought by the national economy.

\subsection{Literature Review}

The study of Miglawi, A. about the relative efficiency of the financial and monetary policies in the economic 
activity - a comparative study between Jordan and Algiers.

The model of (SVAR) was used. The study showed that the financial policy was more effective than the monetary policy in Jordan, while the monetary policy was more effective than the financial policy in the economic activity in Algiers. The effect of the financial policy in Jordan was for a longer period than the financial in Algiers. This study recommended the necessity for co-ordination between the monetary and financial policies to achieve a great level of harmony between them (Miglawi, Ameenah, 2011).

The study of Dirwassi M. was about the financial policy and its role in the achievement of economic equilibrium- Algerian case (1990-2004). The study reached the fact that the expenditure policies were characterized by the growth of public expense and increase of its rates from one year to another due to the expansion of the activity of the state and the decrease of public revenues as a results of the fluctuation of oil prices, which means that relativity between public revenues and expenditure, as the results of the growth of public expenditure was higher than the results of the growth of revenues (Dirwassi, Mas'ood, 2005).

The study of Al- Dureiri was about the role of the financial and monetary policies in the control of inflation in Sudan - an analytical study of the period 1970- 2006. This study showed the existence of a group of interrelated factors which had their impact on inflation in Sudan. They were monetary factors represented in money supply, financial ones represented in budget deficiency and structural ones represented in the increase of the growth rate of the gross domestic product. This study recommended that the state should depend on real resources in funding budget deficiency in order to decrease monetary issue, encourage investment through the system of necessary incentives and facilities and work for the exploitation of available natural resources in Sudan (Ibraheem AlDureiri et al, 2009).

The study of Ali ,et was about the impact of financial and monetary policies on economic growth - and applied study on the Egyptian economy. This study concluded a group of results, the most important of which is that monetary policy has its effect on economic growth, not only through the quantitative instruments, but through the qualitative instruments, and public expenditures affect economic activity through their effect on each of consumption, production and income re - distribution. This study recommended the necessity for directing money supply in the way that meets requirement needs for monetary issues or come near them (Sarah Ali et al, 2013).

The study of Al- heeti \& Ayyoob. was about the role of financial and monetary policies in economic growth. The results of this study revealed that the monetary policy is more effective than the financial one. The study results also emphasized the existence of a one - way effect of the supply of money toward the gross domestic product, stressing the efficiency of the monetary policy over the financial one( Ahmad Al- heeti \&Awss Ayyoob, 2012).

The study of Inraheem \& khair was about the impact of monetary and financing policies on the indicators of the entire economy in Sudan. This study concluded the existence of a positive relationship between exchange and money supply as a variable for monetary policy because the increase of exchange leads to the increase in money supply. The study also concluded the existence of a positive relationship between inflation and money supply as a variable of monetary policy. The study recommended the necessity for a stable monetary policy to maintain the stability of exchange. The government should decrease inflation rate and co- ordinate between the ratios and amounts of monetary policy instruments and determine them in general and homogeneous frame (Hadiyyah Hassan Inraheem \& Muhammad Khair 2013).

The study of Baqbaq was about the effect mechanism of monetary policy in Algeria and its internal components an econometric study. This study, through the econometric results, concluded the absence of the effect of monetary policy on prices which may be due to several reasons, the most important of which is that inflation in Algeria was not only monetary. The study also concluded the absence of the effect of monetary policy on exchange, the fact which made it incapable of playing its role in transferring the effect of monetary policy to the economic activity on Algeria's. According to the researcher, this is because of the low level of open economy, outside the country and the non- availability of the components and incentives of attracting foreign investment. This study recommended the activation of the effect channels of monetary policy, means of activating the breaking system and financial market in Algeria's, as well as the adjustment of the legislative frame of the banking system according to international developments and the encouragement of establishing private and national banks for contributing to the national economy(Baqbaq, Leila Assmahan,2015).

\section{Theoretical Framework}

The financial and monetary policy has an important position in the study of the financial aspects and questions relating to the governmental expenditure and revenue. These policies play an important role in the achievement 
of various aims through their impact on economic activity and equilibrium situation at the level of the national economy. Some scientists have linked the financial policy to the impact of the government on the general purchase power and its use for the public budget of the state to face the economic fluctuations represented in inflation and depression. The economist kinz used the financial policy during the second world war to mean the revenues, expenditures and public debt in the achievement of high levels of the entire production without casing economic inflation. He proved that strong economy could be stable at any level of operation, and not at complete operation as the classical economists believed. The recent aim of the economic policies, in general, has expressed the desire to decrease the equation at the level of complete labor not accompanied by the rise of prices. This aim can be achieved through the activating economic policies with the interference of the state through its financial policies or the monetary or both of them together. Each one of these policies has its special instruments through which it can affect the rates of entire demand and economic activity (AL- Wadi, 2007). Whatever the difference in the views of economists is, co-ordination between both policies is considered important as they have common effects on the economic activity as they seek to achieve equilibrium and stability in all aspects such as labor, prices, production and balance of payment (Mighlawi, 2001).

\subsection{Definition of Economic Policies}

What is meant by economic policies is all that is relating to the different decisions taking, represented by the government for achieving economic and social aims and searching for the best alternatives in order to achieve the desired aim to reach the greatest possible competence when using the available resources to achieve the biggest number of aims. Therefore, the economic policy should be characterized by competence and efficiency in order to achieve high growth rates. Through these policies and the achievement of economic aims, satisfying the society individuals needs for commodities. This can lead to economic growth and increase of job opportunities in society, in a way to solve the problem of unemployment.

The instruments which control the economic system of the state can be divided into:

1) Monetary policy instruments.

2) Financial policy instruments.

\subsection{Definition of Financial and Monetary Policies}

\subsubsection{Monetary Policy}

It is the group of procedures, means and instruments used by the Central Bank, as being a representative of the executive authority in order to affect money supply and credit size, namely, to affect the monetary flow in economy. Most governments in the world, through their monetary policies, seek to achieve the following aims (AL- Taher, 2004):

1) Stability of price.

2) Achievement of satisfactory rates.

3) Decreasing unemployment stability.

4) Maintaining exchange stability.

5) Stability of interest rates.

6) Achieving monetary stability.

The monetary policy affects money supply through its quantitative instruments represented in:

1) Interest rate.

2) Compulsory reserve.

3) Open market operations.

4) Operations of discount price and rediscount.

\subsubsection{Financial Policy}

Financial policy is defined as the group of aims and activities adopted by the state in order to affect the national economy and society, with the aim of maintaining the general stability, solving problems and facing all contingencies. The financial policy, followed by the government, achieves the following aims (AL- Wadi, 2007):

1) Achievement of productive competence.

2) Achievement of complete labor. 
3) Achievement of economic progress.

4) Achievement of equation in income distribution.

5) Achievement of stabilization in the general level of prices.

The government can achieve that through the use of the following instruments of financial policy:

1) Direct and indirect taxes.

2) Support and subsidies.

The impact of these tow policies on the economic activity has been greatly controversial among many economists, at the top of which are the kinzeana (economists who belong to the school of kinz) and critics, as kinz considered the financial policy more effective than the monetary policy in its influence on production and labor, while the critics disagreed with them saying that the monetary policy is more effective. However, their dispute has been narrower when each side realized that each of the tow policies can affect production and prices (Shawaihani, 2005).

In Jordan, the state has had the leading role in guiding the Jordanian economy, through its different stages, by adopting several policies at the top of which are the financial and monetary policies.

Therefore, this study came to shed light on the role of each of the financial policy and monetary policy in the achievement of economic growth and stability in Jordan during the period (2000-2015). For achieving the aim of this study, the researcher designed a measurement model (scale) for this purpose as follows:

$$
Y=\underset{0}{a}+\underset{1}{b} P E+\underset{2}{b M 2}+4
$$

Where:

- The gross domestic product

$-\mathrm{Y}$

- Public expenditure

$-\mathrm{PE}$

- Money Supply

$-\mathrm{M} 2$

- Random variable

$-\mathrm{U}$

There data were analyzed through (SPSS) program and the result was as follows:

$\mathrm{Y}=1415.842+0.299 \mathrm{PE}+0.848 \mathrm{M}$

These results showed the existence of a self- correlation problem where the value of D.W is 0.774 which is less than the value of $\mathrm{DL}=0.982$. The self- correlation problem was processed through the use of LOG for money supply only because it was experimented on all variables and the problem was existing and when applying it on money supply alone, the problem did not appear and the formula was as follows:

$\mathrm{Y}=\alpha+\beta \mathrm{PE}+\beta \log \mathrm{m}_{2}+\mathrm{E}$

$\mathrm{Y}=16249.76+4.139 \mathrm{PE}-3183.997$

$\mathrm{T} \quad 0.461 \quad 4.066$

R square $=97.9$

Adjusted R square $=97.5$

D.W $=1.705$

This signifies that the data were significant at the level (0.01). After that, the effect analysis of each of the financial policy and monetary policy in Jordan was analyzed through (step wise) and the results were as follows:

$\mathrm{Y}=2738.617+3.593 \mathrm{PE}$

$\mathrm{T} \quad-3.781 \quad 25.084$

R square $=97.8$

Adjusted R square $=97.7$

D.W $=1.299$

This means that the financial policy, represented by public expenditure, was more influential on the domestic product in the Jordanian economy, while there was no mentionable influence of the monetary policy. These results were consistent with a lot of the study which were conducted in Jordan about this topic, and as Jordan, 
after the financial crisis of 1989 has had a stable exchange of the dinar since then.

\section{Results}

\subsection{Conclusions}

This means the non- existence of efficiency of the monetary policy in economic activity. Based on that, this study concluded the following results:

1) The financial policy, represented by public expenditures had a positive impact on the economic activity in Jordan during the period of the study.

2) The monetary policy, represented by money supply, had no effect on the economic activity in Jordan during the period of the study.

These results were expected in the Jordanian economy as a result of some measures taken by the government before stabilizing the exchange of the dinar against the dollar in order to increase the citizen trust in the dinar

\subsection{Recommendations}

Based on that, the study recommended the following:

1)Giving the financial policy bigger importance in dealing with some difficulties in the Jordanian economy as being more effective than the monetary policy as shown in the analysis of the results.

2)Giving future importance to the monetary policy through the concentration on Amman Stock Market and the innovation of its instruments in order to contribute to the increase of the role of monetary policy in the economic activity.

3) Increasing the co-ordination between the financial policy and the monetary policy in Jordan and the achievement of a greater possible degree of compatibility between them for the interest of the national economy.

4) Conducting further studies about this topic as it is of great importance for the national economic activity.

\section{References}

Abdullah, A. T., \& Muwafaq, A. K. (2004). - Money, Banks and Financial Institutions - Yazed Centre for Publication - first Ed. - Al- Karak - 2004.

Ahmad, A., \& Awss, A. (2012). The Role of Financial and Monetary policies on Economic Growth - Al-Anbar Magazine for Economic and Administrative Sciences- vol.4- No. 8 - 2012.

Al- Dureidi, I. (2009). The Role of Financial and Monetary policies in the Control of Inflation in Sudan published master thesis -2009 .

Al- Wadi, M. (2000). Principles of General Finance - Dar Al- Masseerah for publication and distribution - First Ed. - Amman - Jordan - 2000.

Baqbaq, L. A. (2015). The Influence Mechanism of the Monetary policy in Algiers and its Internal components on econometric study - published doctoral dissertation - Abi Bakr Bilqayid - Algiers - 2015.

Central Bank of Jordan - different statistical publications.

Department of General Statistics - different statistical publications.

Dirwassi, M. (2005). Financial Policy and its Role in the Achievement of Economic Equilibrium- the case of Algiers- published doctoral dissertation -2005.

Hadiya, I., \& Muhammad, K. (2013). The Impact of Monetary and Financial policy on the Indicators of the Entire Economy in Sudan - Magazine of economic sciences, No.14- Ed. 2 - 2013.

Miglawi, A. (2011). The Relative Efficiency of the Financial and Monetary Policies in Economic Activity - A Comparative study between Jordan and Algiers - UN published master thesis - Mu'tah University - Jordan $-2011$.

Sarah, A. (2013). The Impact of the Financial and Monetary policies on Economic Growth - An Applied study on the Egyptian Economy - Magazine of political sciences and Law- Egypt - 2013.

Shuweikani, H. (2005). the Impact of the Financial and Monetary policies in the Economic Growth in Jordan published master thesis - University of Jordan - Jordan - 2005. 


\section{Appendix A}

Study Variables to Appendix A

\begin{tabular}{lcrc}
\hline year & $\begin{array}{c}\text { Money supply } \\
\text { M2 }\end{array}$ & $\begin{array}{c}\text { Government } \\
\text { expenditure }\end{array}$ & $\begin{array}{c}\text { Nominal } \\
\text { GDP }\end{array}$ \\
\hline 2000 & 7434.7 & 2187.1 & 5998.6 \\
2001 & 7866.1 & 2316.3 & 6393.7 \\
2002 & 8419.1 & 2396.2 & 6794.0 \\
2003 & 9465.7 & 2809.8 & 7228.8 \\
2004 & 10571.4 & 3180.5 & 8090.7 \\
2005 & 13364.0 & 3238.9 & 8925.4 \\
2006 & 14109.7 & 3912.2 & 10675.4 \\
2007 & 15606.8 & 4586.5 & 12131.4 \\
2008 & 18304.3 & 5431.9 & 15593.4 \\
2009 & 30013.3 & 5976.0 & 16912.2 \\
2010 & 22206.7 & 5708.2 & 18762.0 \\
2011 & 24118.9 & 6801.8 & 20476.6 \\
2012 & 24945.1 & 6878.2 & 21965.5 \\
2013 & 27363.4 & 7076.9 & 23851.6 \\
2014 & 29340.4 & 7851.1 & 24437.1 \\
2015 & 31605.5 & 7722.9 & 26637.4 \\
2016 & 32876.2 & 7948.5 & 27444.8 \\
\hline
\end{tabular}

Source: central bank of Jordan -statistical report

\section{Copyrights}

Copyright for this article is retained by the author(s), with first publication rights granted to the journal.

This is an open-access article distributed under the terms and conditions of the Creative Commons Attribution license (http://creativecommons.org/licenses/by/4.0/). 